\title{
ANALISIS PERFORMANSI TURBIN PROPELLER OPEN FLUME TIPE TC 60 KAPASITAS 100-W TERHADAP PERUBAHAN DEBIT
}

\section{PERFORMANCE ANALYSIS OF PROPELLER TURBINE OPEN FLUME TYPE TC 60 WITH 100-W CAPACITY TO DISCHARGE CHANGE}

\author{
Wahyu K. Sugandi ${ }^{1 凶}$, Dwi R Kendarto ${ }^{1}$, Sophia Dwiratna ${ }^{1}$, Arif Rahmanda ${ }^{1}$ \\ ${ }^{1}$ Departemen Teknik Pertanian dan Biosistem, Fakultas Teknologi Industri Pertanian, Universitas Padjadjaran, \\ \omunikasi Penulis, email: sugandiwahyu@gmail.com \\ DOI:http://dx.doi.org/10.23960/jtep-lv10i2.161-169
}

Naskah ini diterima pada 29 Maret 2021; revisi pada 12 April 2021;

disetujui untuk dipublikasikan pada 12 April 2021

\begin{abstract}
The TC 60 open flume propeller turbine is an example of a pico-hydro-based fluid engine. The potential of the TC 60 open flume propeller turbine can be maximized by paying attention to the flow rate. This study aims to analyze the performance of the TC 60 open flume propeller turbine performance which is influenced by changes in discharge. The method used is descriptive analysis method. The turbine performance testing was carried out at the CV Cihanjuang Inti Teknik laboratory in Cimahi. Turbine testing begins by making 9 discharge ranges from 1.28 litre/sec until 4.85 litre/sec then testing each of these flows. Power testing is carried out using a lamp load of 10 to 100 watts. The results showed the effect of changes in discharge on the power generated by the turbine. The maximum power produced in this study is 74 watts at a discharge flow of 4.85 litre/sec with a load of 70 watts. The lowest discharge to be able to move the turbine is 1.28 litre/sec. The results of the technical feasibility analysis on civil buildings in CV Cihanjuang Teknik show that the TC 60 open flume propeller turbine is feasible to use by considering the design of the discharge, head and channel shape of civil buildings.
\end{abstract}

\section{Keywords: discharge, picohydro, propeller turbine, performance}

\begin{abstract}
ABSTRAK
Turbin propeller open flume TC 60 merupakan salah satu contoh dari mesin fluida yang berbasis pikohidro. Potensi dari turbin propeller open flume TC 60 dapat dimaksimalkan dengan memperhatikan aliran debit Penelitian ini bertujuan menganalisa performansi dari turbin propeller open flume TC 60 yang dipengaruhi oleh perubahan debit. Metode yang digunakan adalah metode anallisis deskriptif. Pengujian kinerja turbin dilaksanakan di laboratorium CV Cihanjuang Inti Teknik Kota Cimahi. Pengujian turbin dimulai dengan membuat 9 rentang debit air yaitu mulai dari 1,28 liter/detik hingga 4,85 liter/detik kemudian dilakukan pengujian pada setiap debit air tersebut Pengujian daya dilakukan menggunakan beban lampu 10 sampai 100 watt Hasil penelitian menunjukan adanya pengaruh dari perubahan debit terhadap daya yang dihasilkan oleh turbin. Daya maksimal yang dihasilkan ini adalah 74 watt pada aliran debit 4,85 liter/detik dengan beban 70 watt, sedangkan debit terendah untuk dapat menggerakan turbin adalah sebesar 1,28 liter/detik Hasil analisa kelayakan teknis terhadap bangunan sipil air di Laboratorium CV Cihanjuang Teknik menunjukan bahwa turbin propeller open flume TC 60 layak untuk digunakan dengan mempertimbangkan desain debit, head dan bentuk saluran bangunan sipil.
\end{abstract}

Kata kunci : debit, pikohidro, turbin propeller, performansi

\section{PENDAHULUAN}

Energi merupakan bagian penting dalam kehidupan masyarakat karena hampir seluruh aktivitas manusia selalu membutuhkan energi. Energi yang digunakan di Indonesia khususnya masih banyak dalam bentuk minyak bumi, gas alam dan batu bara. Seluruh sumber energi tersebut bisa segera habis apabila digunakan secara terus-menerus tanpa memikirkan alternatif sumber energi terbarukan (Marsudi, 2005). Ada beberapa sumber energi terbarukan yang dapat digunakan sebagai alternatif pengganti sumber energi tak terbaharui yaitu 
sumber energi air, sumber energi matahari, sumber energi angin dan sumber energi panas bumi (Azharuddin, 2010).

Mengacu pada bentuk iklim tropis Indonesia, terdapat banyak sumber energi terbaharukan yang dapat dijadikan sebagai sumber energi alternatif pengganti energi tak terbaharui. Salah satu dari sumber energi yang banyak ditemukan di Indonesia adalah sumber energi air. Indonesia memiliki banyak sekali sumber air yang bisa dimanfaatkan sebagai sumber energi alternatif pengganti sumber energi tak terbaharui. Bentang alam dalam bentuk gugusan pulau beriklim tropis, Indonesia memiliki berbagai sumber energi air yang meliputi danau, air terjun, sungai dan laut (Azharuddin, 2010).

Sumber energi air dapat digunakan sebagai sumber daya air untuk menghasilkan berbagai macam jenis energi yang bermanfaat bagi kehidupan masyarakat. Salah satu bentuk pemanfaatan sumber daya air sebagai sumber energi adalah merubah energi air dalam bentuk energi mekanik menjadi energi kinetik (gerak) dan energi potensial. Energi mekanik dari air dapat diubah menjadi energi yang bisa dimanfaatkan masyarakat seperti energi listrik. Mengubah energi kinetik air agar menjadi energi listrik dibutuhkan sebuah alat untuk mengkonversikan yang disebut dengan turbin (Munson, 2003)

Turbin adalah suatu mesin yang digunakan untuk mengkonversikan energi mekanik menjadi energi listrik. Energi listrik pada turbin terbentuk dari perubahan energi mekanik oleh generator. Menurut Micheal Faraday aliran atas muatan listrik dapat diinduksi dengan memindahkan sebuah konduktor listrik seperti kawat yang mengandung listrik dalam sebuah magnet (Wibowo, 2007).

Pemanfaatan turbin sebagai alat untuk mengkonversi energi, telah banyak dilakukan inovasi untuk berbagai macam situasi dan kondisi alam. Danau, waduk dan laut dapat menghasilkan energi yang sangat besar sehingga dibutuhkan turbin berkapasitas besar untuk memanfaatkan energinya. Sungai-sungai kecil memiliki potensi menghasilkan energi listrik sehingga dibutuhkan turbin berkapasitas rendah untuk memanfaatkan energinya (Dwiyanto dan Bery, 2016).

Kesadaran manusia akan pemanfaatan sumber air kecil mendorong berkembangnya teknologi turbin berkapasitas rendah. Pengembangan teknologi turbin berkapasitas rendah dikenal sebagai pembangkit listrik tenaga microhydro. Pemilihan turbin untuk pembangkit listrik microhydro ini bergantung pada lokasi yang akan dibangun pembangkit listrik tersebut (Nugraha, Waluyo dan Syahrial, 2013). Salah satu jenis turbin untuk pembangkit listrik microhydro adalah turbin jenis propeller open flume. Turbin propeller memanfaatkan tinggi jatuhan air efektif (net head) yang rendah dan debit air untuk beroperasi menghasilkan energi listrik. Jatuhan air yang rendah dapat dimanfaatkan secara maksimal menggunakan turbin jenis propeller (Dwiyanto dan Bery, 2016).

Pengembangan turbin propeller skala kecil (turbine Propeller Open Flume pikohydro) telah dilakukan oleh salah satu perusahaan konstruksi di kawasan industri Kota Cimahi yang bernama CV Cihanjuang Inti Teknik. CV Cihanjuang Inti Teknik bergerak dalam bidang industri rekayasa material dan produksi berbagai macam turbin. Salah satu hasil produksi CV Cihanjuang Inti Teknik yang merupakan pengembangan dari turbin pikohydro yaitu turbin Propeller Open Flume TC 60. Turbin jenis ini merupakan turbin kecil yang dapat menghasilkan daya listrik 120 watt. Turbin propeller open flume TC 60 dapat dioperasikan pada head rendah $3 \mathrm{~m}$ sehingga mudah untuk diaplikasikan pada sungai beraliran debit kecil.

Turbin Propeller Open Flume TC 60 memiliki dimensi $100 \mathrm{~mm} \times 100 \mathrm{~mm} \times 600 \mathrm{~mm}(\mathrm{P} \times \mathrm{L} \times \mathrm{T})$ sehingga bisa diterapkan pada daerah yang memiliki sumber air kurang dari 6 liter/detik. Turbin ini memiliki daya keluaran bersih sebesar $100 \mathrm{~W}$ yang bisa digunakan sebagai sumber listrik diberbagai bidang kehidupan industri rumahan seperti tambak dan pertanian.

Mengacu pada data sheet yang dikeluarkan oleh CV Cihanjuang Inti Teknik belum adanya spesifikasi lengkap mengenai perlakuan debit turbin propeller open flume TC 60. Untuk itu perlu di lakukan penelitian uji performansi 
turbin propeller open flume TC 60 dengan berbagai perlakuan debit air.

\section{BAHAN DAN METODE}

Metode yang digunakan dalam penelitian ini adalah metode analisis deskriptif. Penelitian ini di lakukan di laboratorium CV Cihanjuang Inti Teknik, Cimahi, Jawa Barat. Alat dan Bahan yang digunakan pada penelitian ini adalah aliran air sungai cihanjuang yang di bendung oleh CV Cihanjuang Inti Tekik. turbin propeller open flume TC 60 (Gambar 1) dan (Tabel 1) current meter tachometer (GM8950), meteran, lampu pijar, stopwatch, multimeter digital, dan tachometer. Adapun tahapan penelitian seperti yang disajikan pada Gambar 2.

Tahapan penelitian ini dimulai dengan mengukur debit yang mengalir pada saluran uji laboratorium (Gambar 3). Setelah didapatkan debit dilanjutkan dengan melakukan pengujian pada turbin disetiap debit yang telah diuji menggunakan beban lampu pijar. Pengujian dilakukan masing-masing lima kali pengulangan disetiap debit yang ditentukan.

\subsection{Pengukuran Debit}

Pengukuran debit dilakukan dengan menggunakan persamaan berikut:

$$
\mathrm{Q}=\mathrm{A} \times \mathrm{v} \times \mathrm{t} \times 0,85
$$

Dimana, $\mathrm{Q}$ adalah debit (liter/detik), A adalah luas saluran $\left(\mathrm{cm}^{2}\right), V$ adalah kecepatan aliran (detik), dan $t$ adalah ketinggian saluran .

\subsection{Pengukuran Daya Input}

Pengukuran daya input dilakukan dengan menggunakan Persamaan 2.

$$
\mathrm{P}_{\text {air }}=\rho \times \mathrm{g} \times \mathrm{Q} \times \mathrm{H}
$$

Dimana, $\rho$ merupakan massa jenis air $(1000 \mathrm{~kg} /$ $\left.\mathrm{m}^{3}\right)$, g adalah gravitasi $\left(\mathrm{m} / \mathrm{s}^{2}\right), \mathrm{Q}$ adalah debit air $\left(\mathrm{m}^{3} / \mathrm{s}\right)$, dan $\mathrm{H}$ adalah beda tinggi elevasi (head) (m).

\subsection{Pengujian Turbin}

Pengujian turbin dilakukan pada saat debit air telah diketahui $(1,28,172,2,18,2,54,3,21,3,67$, $4,03,4,49$, dan 4,85) dengan cara mengukur menggunakan current meter kemudian dilakukan pengujian turbin menggunakan beban lampu $(10,20,30,40,50,60,70,80,90$ dan 100$) \mathrm{W}$ untuk dengan cara mengukur tegangan, arus dan

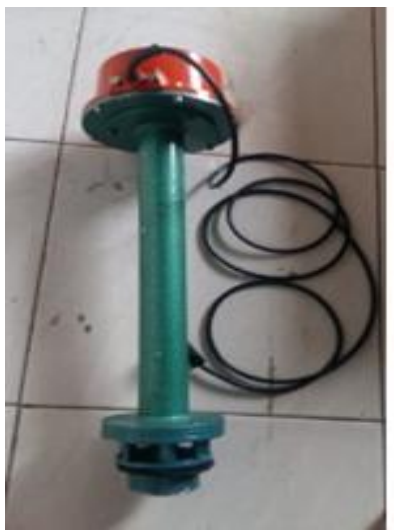

Gambar 1. Turbin Propeller Open Flume TC 60

Tabel 1. Spesifikasi Turbin Propeller Open Flume TC 60

\begin{tabular}{ll}
\hline Jenis Turbin & Propeller Open Flume \\
\hline Jenis Generator & Permanen Magnet \\
Tegangan & $200-220$ volt \\
Tegangan tanpa beban & \pm 300 volt \\
Frekuensi & $90 \mathrm{~Hz}$ \\
Putaran & $\pm 2700 \mathrm{rpm}$ \\
Disain Head & $3 \mathrm{~meter}$ \\
Desain debit & $5,5 \mathrm{liter} /$ detik \\
Ratting Power & $100 \mathrm{watt}$ \\
\hline
\end{tabular}




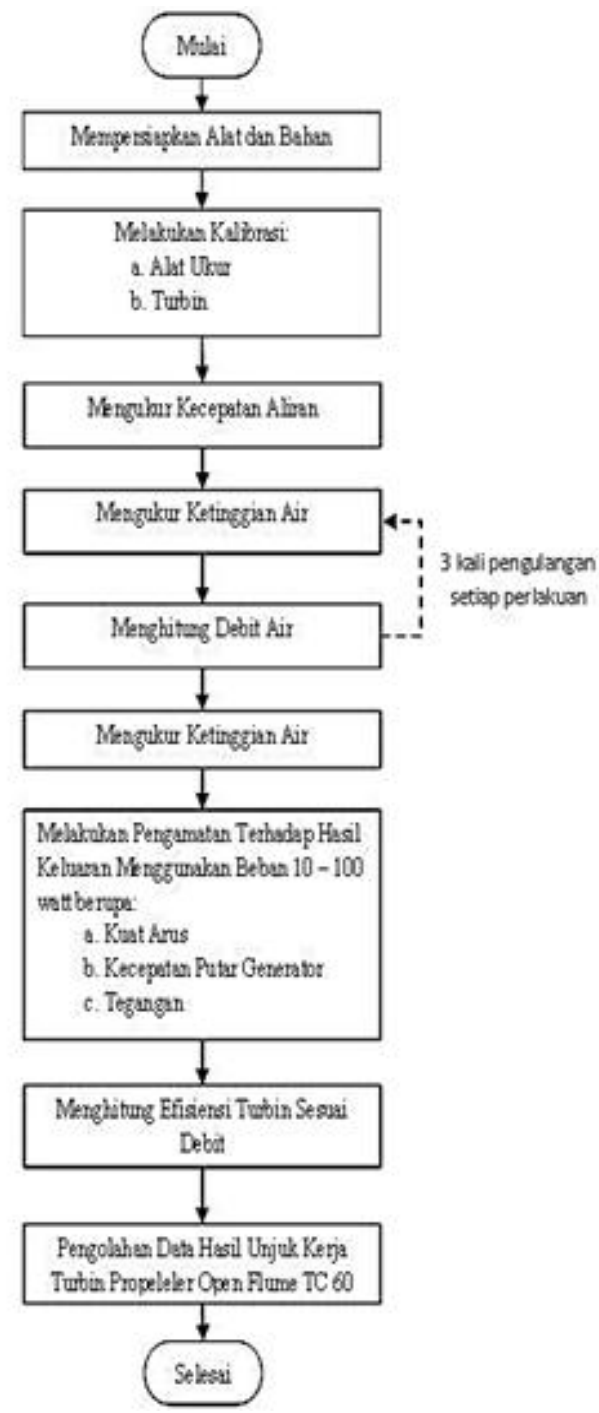

Gambar 2. Tahapan Penelitian

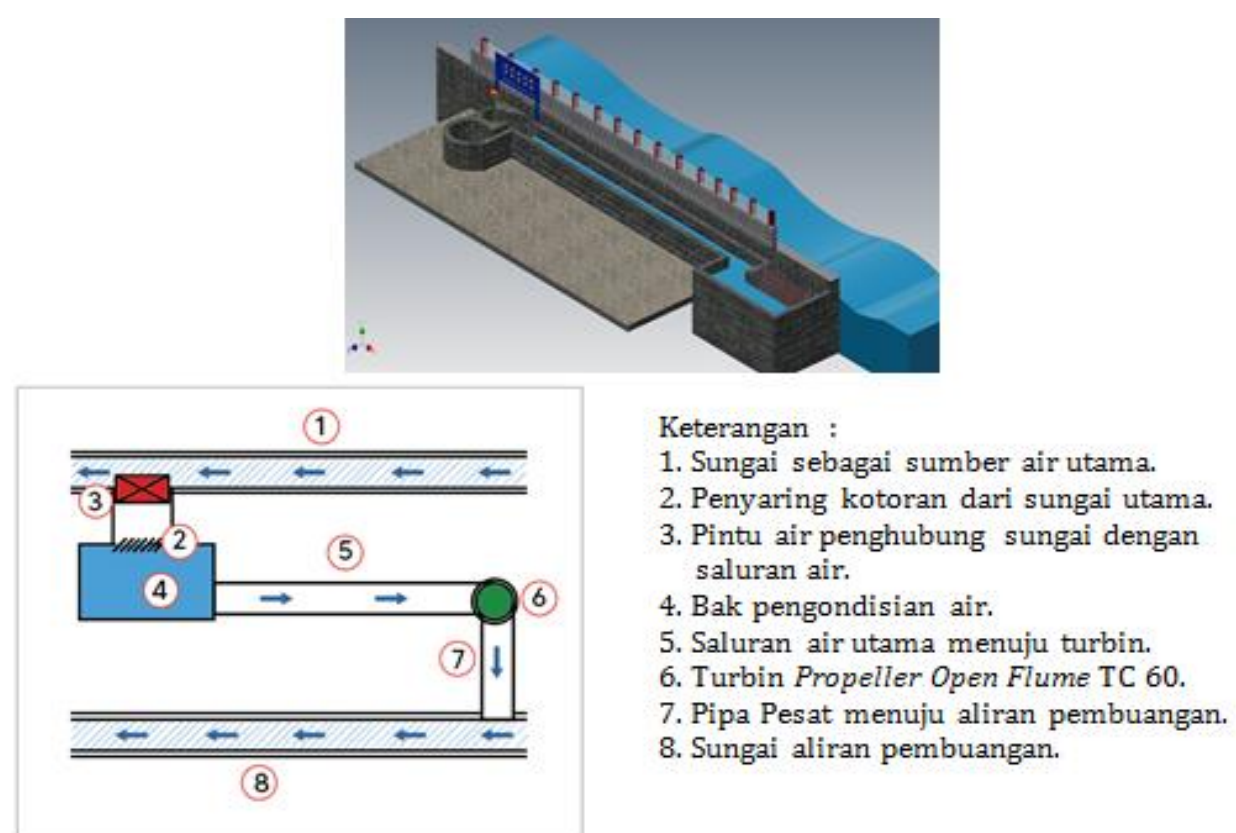

Gambar 3. Skematik Pengukuran Debit 
kecepatan putar turbunyang terbaca pada alat ukur multimeter digital dan tachometer. Untuk analisa unjuk performansi turbin akan mengacu pada standar Nasional Indonesia 04-1930-1996.

\section{HASIL DAN PEMBAHASAN}

\subsection{Hasil Pengukuran Debit}

Berdasarkan hasil pengukuran dengan kecepatan air $1 \mathrm{dm} /$ detik dan luas penampang saluran air diperoleh debit air seperti yang disajikan pada Tabel 2.

\subsection{Tinggi Jatuhan Air}

Tinggi jatuhan air bedasarkan lokasi pengambilan data di laboratorium Cihanjuang Inti Teknik adalah $3 \mathrm{~m}$. Ketinggian ini didesain untuk mendapatkan debit air yang besar dari tinggi permukaan air masuk pada turbin menuju ke pipa pesat yang terhubung langsung ke sungai.
Saluran pipa pesat inilah yang menyebabkan air dapat menggerakan propeller blade turbin. Pergerakan propeller blade akan diteruskan menuju generator dalam bentuk energi kinetik. Selanjutnya energi kinetik tersebut dirubah menjadi energi listrik oleh generator. Adapun layout dari skematik ketinggian jatuh air dari laboratorium Cihanjuang Inti Teknik seperti yang di sajikan pada Gambar 4.

\subsection{Daya Teoritis Turbin Propeller Open Flume TC 60}

Berdasarkan dari hasil perhitungan dari beberapa debit yang diukur diperoleh daya teoritis turbin propeller open flume TC 60 sesuai Persamaan 2 adalah seperti yang disajikan pada Tabel 3. Daya teoritis ini akan digunakan sebagai nilai pembanding untuk mendapatkan nilai efisiensi dari beban yang akan digunakan dalam pengujian. Daya teoritis pada turbin atau lebih

Tabel 2. Debit Air Berdasarkan Luas Penampang

\begin{tabular}{ccc}
\hline No. & Luas Penampang Basah $\left(\mathbf{d m}^{\mathbf{2}}\right)$ & Debit $\mathbf{( L / s )}$ \\
\hline 1 & 1,28 & 1,28 \\
2 & 1,72 & 1,72 \\
3 & 2,18 & 2,18 \\
4 & 2,54 & 2,54 \\
5 & 3,21 & 3,21 \\
6 & 3,67 & 3,67 \\
7 & 4,03 & 4,03 \\
8 & 4,49 & 4,49 \\
9 & 4,85 & 4,85 \\
\hline
\end{tabular}

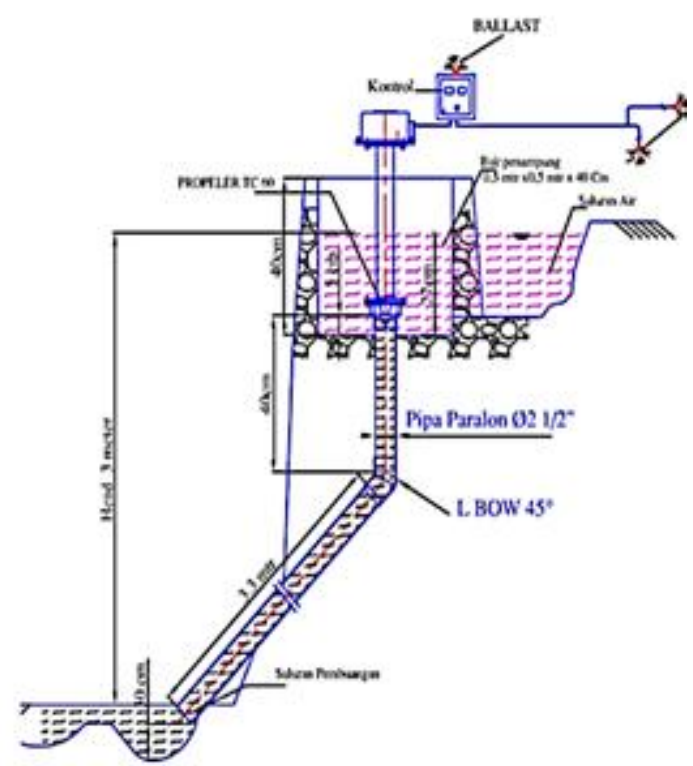

Gambar 4. Layout Tinggi Jatuh Air Laboratorium Cihanjuang Inti Teknik 
Tabel 3. Daya Teoritis Berdasarkan Debit Air yang Dikur

\begin{tabular}{cc}
\hline Nilai Debit (L/s) & Daya Teoritis (W) \\
\hline 1,28 & 31,98 \\
1,72 & 42,98 \\
2,18 & 54,47 \\
2,54 & 63,47 \\
3,21 & 80,21 \\
3,67 & 91,70 \\
4,03 & 100,70 \\
4,49 & 112,20 \\
4,85 & 121,20 \\
\hline
\end{tabular}

dikenal dengan daya output turbin adalah daya yang dapat dihasilkan secara maksimal oleh turbin dengan memperhitungkan ketinggian head dan efisiensi turbin. Dengan efisiensi turbin sebesar $85 \%$.

\subsection{Daya Aktual Turbin Propeller Open Flume TC 60}

Berdasarkan hasil pengukuran dengan menggunakan Multimeter digital yang disambungkan dengan stabilizer output. Daya aktual turbin propeller open flume TC 60 untuk debit sebesar 1,28 liter/detik menunjukan bahwa daya maksimal yang dapat terbaca oleh multimeter adalah sekitar 25 W. Daya tersebut terhitung pada saat pembebanan lampu sebesar 30 W. Pada saat pengujian nilai daya yang terbaca akan semakin menurun dikarenakan beban yang dipasangi pada turbin telah melebihi kapasitas maksimal yang dapat dipasang. Jika diperhatikan pada saat pengujian lampu dapat menyala semua akan tetapi dengan intensitas yang sangat redup. Hal ini disebabkan adanya pembagian daya yang merata pada rangkaian paralel yang terpasang pada skematik kelistrikan laboratorium cihanjuang inti teknik.

Seluruh hasil pengukuran daya aktual turbin propeller open flume TC 60 menunjukan angka maksimal sesuai dengan batasan daya maksimal yang dihasilkan turbin. Untuk aliran debit 3,67 liter/detik dipasangkan beban lampu kurang lebih $90 \mathrm{~W}$, terbaca pada angka $70 \mathrm{~W}$. Hal ini karena terjadi adanya penurunan tegangan yang terjadi pada beban 70 watt. penurunan tegangan terjadi adanya kendala pada sistem load control dan kerusakan pada generator magnet.

Kendala pada load control terutama pada kurangnya perawatan secara berkala.
Perawatan berkala secara terhadap sistem load control akan sangat mempengaruhi hasil keluaran dari turbin. Secara teoritis fungsi dari load control adalah untuk menstabilkan tegangan dan arus kedalam rangkaian paralel. Apabila terjadi sedikit kendala dari load control maka akan sangat mempengaruhi hasil daya keluaran turbin.

\subsection{Pengukuran Generator Tanpa Beban}

Pengujian generator tanpa beban dihitung menggunakan tachometer. Adapun nilai kecepatan putar dan tegangan yang terjadi saat pengukuran dengan berbagai tingkatan debit air seperti tersaji pada Tabel 4. Berdasarkan Tabel 4, nilai dari putaran generator akan selalu naik seiring dengan kenaikan debit yang terjadi. Perubahan debit sangat berpengaruh pada putaran generator. Putaran generator turbin yang melebihi angka $3000 \mathrm{rpm}$ disebabkan oleh tidak adanya beban yang mempengaruhi generator.

Putaran generator memiliki perbandingan lurus dengan besaran debit air yang mendorong propeller turbin. Semakin besar debit air maka akan semakin besar pula putaran turbin yang akan terjadi. Sebaliknya, semakin kecil debit air maka akan semakin kecil pula putaran generator yang terjadi.

Pengukuran generator tanpa beban mengakibatkan kenaikan tegangan yang terbaca pada load control dan multimeter. Kenaiakan tegangan terjadi karena tidak ada nya pendistribusian daya yang terjadi dari load control. Diputusnya distribusi daya pada loud control mengakibatkan lonjakan daya sehingga terjadi kenaikan tegangan seperti yang terjadi pada saat pengukuran daya tanpa beban. 


\subsection{Pengukuran Generator dengan Beban}

Pengukuran generator berbeban adalah pengukuran yang dilakukan untuk mengetahui daya yang dihasilkan turbin secara aktual. Pengukuran yang dilakukan tanpa beban tidak akan dapat diketahui berapa daya yang dihasilkan oleh turbin karena tidak adanya arus yang dapat terbaca pada multimeter dan loud control. Pengukuran generator ini menggunakan 10 buah beban lampu pijar dengan daya masingmasing $(10,20,30,40,50,60,70,80,90$ dan 100) W. Pengukuran dilakukan pada setiap beban saat di aliri oleh suatu debit.

Penggunaan beban pada generator menunjukan nilai yang sangat variatif (Tabel 5). Perbedaan debit dan perbedaan beban yang dipakai sangat berpengaruh terhadap hasil pengukuran. Pada pengukuran debit 4,85 liter/detik secara teoritis dapat menghasilkan daya puncak sebesar $74 \mathrm{~W}$, akan tetapi pada saat pengujian di lapangan daya puncak yang dapat dihasilkan oleh debit 4,85 liter/detik adalah $70 \mathrm{~W}$. Hal ini bisa terjadi dikarenakan banyak faktor seperti penyebaran daya lampu pada rangkaian paralel, dan kerusakan pada turbin.

\subsection{Efesiensi Turbin Propeller Open Flume TC 60}

Perhitungan nilai efisiensi turbin dilakukan dengan membandingkan daya keluaran turbin $\left(\mathrm{P}_{\text {out }}\right)$ dengan daya masukan turbin secara teoritis $\left(\mathrm{P}_{\text {in }}\right)$. Perhitungan efisiensi ini dilakukan pada semua debit dan semua beban lampu sehingga terdapat sejumlah data.

Efisiensi pada pengujian turbin propeller open flume TC 60 sangat bergantung pada perubahan debit. Perubahan debit mempengaruhi data pengukuran berupa kuat arus dan tegangan, sehingga mempengaruhi daya keluaran yang terbaca pada saat pengukuran. Pada debit 1,28 liter/detik didapatkan nilai efisiensi terbaik pada pemasangan beban 30 watt. Hal ini bisa terjadi karena daya keluaran turbin yang terbaca saat pengukuran adalah $25,74 \mathrm{~W}$ yang dimana angka pengukuran tersebut sudah mendekati nilai daya maksimal yang bisa dihasilkan oleh turbin yaitu $31,98 \mathrm{~W}$. Sehingga nilai efisiensi dari debit 1,28 liter/detik adalah $80 \%$. Nilai efisiensi ini terbilang cukup baik karena mendekati nilai $85 \%$ yang tertulis pada data sheet turbin propeller open flume TC 60.

Tabel 4. Nilai Tegangan dengan Berbagai Tingkatan Debit Air

\begin{tabular}{ccc}
\hline Debit Air (liter/detik) & Putaran Generator (rpm) & Tegangan (V) \\
\hline 1,28 & 3268 & 230 \\
1,72 & 3300 & 231 \\
2,18 & 3325 & 235 \\
2,54 & 3387 & 235 \\
3,21 & 3498 & 234 \\
3,67 & 3548 & 231 \\
4,03 & 3675 & 240 \\
4,49 & 3758 & 238 \\
4,85 & 3836 & 237 \\
\hline
\end{tabular}

Tabel 5. Besaran Daya pada Debit 4,85 liter/detik

\begin{tabular}{cccccc}
\hline No & Beban & RPM & Voltase (V) & Kuat Arus (A) & Daya (Watt) \\
\hline 1 & 10 & 2641 & 221 & 0,07 & 15,47 \\
2 & 20 & 2549 & 232 & 0,1 & 23,2 \\
3 & 30 & 2511 & 231 & 0,15 & 34,65 \\
4 & 40 & 2439 & 232 & 0,23 & 53,36 \\
5 & 50 & 2344 & 223 & 0,25 & 55,75 \\
6 & 60 & 2319 & 222 & 0,32 & 71,04 \\
7 & 70 & 2253 & 198 & 0,37 & 73,26 \\
8 & 80 & 2197 & 197 & 0,38 & 74,86 \\
9 & 90 & 2083 & 193 & 0,36 & 69,48 \\
10 & 100 & 2008 & 190 & 0,34 & 64,6 \\
\hline
\end{tabular}


Perhitungan efisiensi terbaik terjadi pada aliran debit 3,21 liter/detik yaitu 83\%. Hal ini bisa terjadi karena nilai daya keluaran dibandingkan dengan daya yang bisa dihasilkan oleh turbin berbanding sangat tipis. Efisiensi terbaik ini terjadi pada saat penggunaan beban $80 \mathrm{~W}$. Akan tetapi pada saat efisiensi terbaik ini sudah terjadi penurunan tegangan dimana tegangan yang terjadi pada saat efisiensi ini terbentuk adalah 198 V. Pada saat penggunaan secara umum tegangan dibawah $220 \mathrm{~V}$ dapat mengakibatkan kerusakan pada alat-alat kelistrik yang terpasang sebagai beban. Penggunaan lampu pijar untuk pengujian di nilai efektif untuk menghindari kerusakan pada beban pada saat terjadi kenaikan atau penurunan tegangan.

\subsection{Analisa Kelayakan Teknis Turbin Propeller Open Flume TC 60}

Berdasarkan data pengukuran yang diperoleh mengenai performansi turbin propeller open flume TC 60, dapat di analisa beberapa faktor yang akan berpengaruh pada kelayakan teknis bangunan sipil pendukung turbin ini.

\section{Bentuk Saluran Bangunan Sipil}

Bentuk dari saluran bangunan sipil harus sangat diperhatikan, pada penelitian ini dimana saluran yang digunakan adalah bangunan sipil ganda untuk pemasangan dua turbin dengan kapasitas berbeda. Bangunan sipil yang terdapat pada laboratorium CV Cihanjuang Inti Teknik di desain supaya dapat digunakan untuk dua mesin fluida yang berbeda sehingga apabila keduanya di jalankan akan mengakibatkan terganggunya salah satu performa dari mesin fluida yang terpasang. Untuk bangunan sipil saluran turbin propeller open flume TC 60 dengan memperhatikan ketinggian air tidak melebihi 30 $\mathrm{cm}$. Apabila bangunan sipil turbin dibuat melebihi ketinggian maksimal yang dapat diterima oleh turbin ini maka generator turbin yang dilindungi oleh housing akan tenggelam oleh air dan mengakibatkan korsleting pada generator.

\section{Desain debit air}

Desain debit air sangat berpengaruh pada pembangunan bangunan sipil turbin propeller open flume TC 60. Pada desain debit air belum memiliki sebuah bak pengondisian air sehingga air dapat mengalir menuju ke turbin. Apabila debit air yang mengalir tidak stabil dan mengalami lonjakan yang cukup drastis akan berdampak pada kelebihan air pada ujung saluran, yang dimana saluran tidak dapat menampung lonjakan debit sehingga air akan tumpah dan bahkan dapat menenggelamkan turbin.

\section{Head Bangunan Sipil}

Tinggi jatuhan air (Head) merupakan hal yang perlu diperhatikan pada saat pembuatan bangunan sipil turbin ini. Jika jatuhan air tidak sesuai dengan desain bangunan yang ada, maka akan terjadi penurunan daya yang bisa dihasilkan oleh turbin. Berdasarkan hasil pengukuran, apabila ketinggian head sesuai dengan spesifikasi yang diberikan oleh CV Cihanjuang Inti Teknik, maka antara daya perhitungan dengan daya aktual akan mengalami tingkat efisiensi yang tinggi sesuai dengan standar dari CV Cihanjuang Inti Teknik.

\section{KESIMPULAN}

Semakin tinggi debit maka daya yang dihasikan akan semakin besar. Efeseinsi yang paling baik adalah pada debit 3,21 liter/detik dengan nilai efesiensi adalah 83\%. Pemberian beban semakin tinggi pada generator akan mengakibatkan melambatnnya putaran generator turbin. Daya maksimal yang dihasilkan ini adalah $74 \mathrm{~W}$ pada aliran debit 4,85 liter/detik dengan beban $70 \mathrm{~W}$.

\section{DAFTAR PUSTAKA}

Arismunanda. 1982. Teknik Tenaga Listrik Jilid 1. Jakarta: Pradaya Paramitha.

Arismunandar, A, dan S Kuwahara. 2004. Teknik Tenaga Listrik Pembangkitan dengan Tenaga Air. Jakarta: Pradaya Paramitha.

Azharuddin, H. 2010. Studi Awal Perencanaan Sistem Mekanikal dan Kelistrikan Pembangkit Listrik Tenaga Mikrohidro Pada Desa Penyandingan Kab. Oku Selatan. Jurnal Austenit 1(3): 28-34 
Dandekar, M.M, dan K.N Sharma. 1991. Buku Pembangkit Listrik Tenaga Air. Jakarta: Universitas Indonesia.

Dwiyanto V., K. D. Indriana, dan Tugiono, S. 2016. Analisis Pembangkit Listrik Tenaga Mikro Hidro (PLTMH) Studi Kasus / : Sungai Air Anak (Hulu Sungai Way Besai). JRSDD 4(3): 407-422

Hendar dan Ujang. 2007. Desain, Manufacturing Dan Instalasi Turbin Propeller Open Flume Diameter $125 \mathrm{~mm}$ Di CV Cihanjuang Inti Teknik Cimahi Jawa Barat. Bogor: IPB.

Kusdiana, Dadan, dan dkk. 2008. Pedoman Teknis Standarisasi Peralatan dan Komponen Pembangkit Listrik Tenaga Microhydro. Jakarta: Direktorat Jendral Listrik dan Pemanfaatan Energi Departemen Energi dan Sumber Daya Mineral.

Marsudi, D. 2005. Pembangkit Energi Listrik. Jakarta: Erlangga.

Munson, R. Bruce. 2003. Mekanika Fluida. 4 ed. Jakarta: Erlangga.

Nugraha, Ihfazh, Waluyo, dan Syahrial. 2013. Penerapan Dan Analisis Pembangkit Listrik Tenaga Pikohidro Dengan Turbin
Propeller Open Flume TC 60 Dan Generator Satu fasa 100 VA Di UPI Bandung. Jurnal Reka Elkomika Itenas 1(4): 328-338

SNI No. 04-193-1996. Syarat Pengujian Turbin Air Mini.

SNI No. 03-2819-1992. "Tata Cara Pengukuran Debit Sungi dan Saluran Terbuka Dengan Alat Ukur Arus Tipe Baling-Baling"

Stevenson, William D. 1994. Analisis Sistem Tenaga Listrik Edisi keempat. 4 ed. Jakarta: Erlangga.

Subekti, R.A. dan Susatyo, A. 2015. Pengujian Prototipe Turbin Head Sangat Rendah Pada Suatu Saluran Aliran Air. Bandung: Pusat Penelitian Tenaga Listrik dan Mekatronik, LIPI.

Tobing, D.L. 1996. Fisika Dasar 1. Jakarta: Gramedia.

Wibowo, Prayatmo. 2007. Turbin Air. Jakarta: Graha Ilmu.

Wiranto, Arismunanda. 1977. Penggerak Mula Turbin. Bandung: ITB. 